results above. They envisage a membrane composed principally of fibrils of a lipoprotein, elenin, lying parallel to the cell surface and cemented together by ether-soluble lipids.

If the structure of the red-cell membrane suggested by Moskowitz \& Calvin is accepted, then the physical dissolution of red cells might proceed as follows: when the cells are suspended in a fresh saline medium the surface lipids will dissolve or disperse in the medium, the lipoprotein which was held in position by the lipids will then become detached and diffuse away. In a medium maintained continuously unsaturated with respect to the lipid components of the cell membrane this process will continue until so much of the lipoprotein has unravelled that the intact existence of the cell is no longer possible. The increase in the rate of haemolysis below $5^{\circ}$ could result from a hardening of the cementing lipids, if the repair of small breaches in the membrane depended on their ability to flow. Recent investigations of the effects of thermal shock on red cells suggest that such a hardening of the lipids does in fact occur (Lovelock, 1955).

The free energy of the lipid components of a highly organized structure such as the red-cell membrane may be higher than that of the same components in their saturated solution. It follows that the red-cell membrane is probably unstable in a physical sense and its intact existence may well depend upon the continuous synthesis of lipid components, and upon the presence of a considerable reserve of membrane material. The observed slow deterioration of living cells stored at $-7^{\circ}$ where all but diffusion processes are slowed to a negligible level is in accord with this notion.

\section{SUMMARY}

1. The effects on human red cells of repeated washing and of exposure to a neutral adsorbent substance, alumina, has been observed. Both of these treatments were found to remove considerable quantities of the lipid components of the cell membrane, and to cause a reduction of the cell volume.

2. The losses sustained by the cells during these treatments could not be reversed, but were not immediately harmful. Only slight haemolysis took place during and after detachment of up to $30 \%$ of their membrane materials.

3. The physical stability and architecture of the red-cell membrane is discussed in the light of these observations.

\section{REFERENCES}

Altman, K. I. (1953). Arch. Biochem. Biophys. 42, 478.

Bloor, W. R. (1916). J. biol. Chem. 24, 227.

Gould, R. G. (1951). Amer. J. Med. 11, 209.

Koch, F. C. \& McMeekin, T. L. (1924). J. Amer. chem. Soc. 46, 2066.

Loutit, J. F., Mollison, P. L. \& Young, I. M. (1943). Quart. J. exp. Physiol. 32, 183.

Lovelock, J. E. (1954). Nature, Lond., 173, 659.

Lovelock, J. E. (1955). Brit. J. Haematol. 1, 117.

Mitchison, M. J. (1953). J. exp. Biol. 30, 397.

Moskowitz, M. \& Calvin, M. (1952). Exp. Cell Res. 3.33.

Muir, H. M., Neuberger, A. \& Perrone, J. C. (1952). Biochem. J. 52, 87.

Muir, H. M., Perrone, J. C. \& Popják, G. (1951). Biochem.J. 48, iv.

Ponder, E. (1948). Haemolysis and Related Phenomena. London: J. A. Churchill Ltd.

Ponder, E. (1954). Nature, Lond., 173, 1139.

Youngberg, G. E. \& Youngberg, M. V. (1930). J. Lab. clin. Med. 16, 158.

\title{
The Determination of Glutathione in Blood and Tissues
}

\author{
By S. K. BHATTACHARYA, J. S. ROBSON AND C. P. STEWART \\ Department of Clinical Chemistry, University of Edinburgh, and Clinical Laboratory, \\ Royal Infirmary, Edinburgh
}

(Received 28 February 1955)

Several methods have been suggested for determining glutathione, in the reduced or sulphydryl form (GSH), and among those applied to biological materials are: iodine titration (Tunnicliffe, 1925; Woodward \& Fry, 1932; Fujita \& Numata, $1938 a$ ), silver nitrate titration (Benesch \& Benesch, 1950), colour development with sodium nitroprusside (Fujita \& Numata, 1938c; Grunert \& Phillips, 1951), arsenophosphotungstic acid (Bene- dict \& Gottschall, 1933) or phospho-18-tungstic acid (Potter \& Franke, 1935), reduction of potassium ferricyanide (Mason, 1930), and coenzyme activity in the glyoxalase system (Woodward, 1935). Although all these methods can give accurate results with glutathione in pure aqueous solution, only the glyoxalase method can be regarded as reliable in biological materials. The others are all subject, in varying degree, to inter- 
ference by ascorbic acid, cysteine, ergothioneine, phenols, uric acid, etc.-substances for which no convenient means of removal as yet exists. The glyoxalase method, however, is claimed to be entirely free from interference by these substances (Lohmann, 1932; Woodward, 1935).

Glutathione in the oxidized or disulphide form (GSSG) is not detected by any of these procedures. Since it is reducible to the sulphydryl form, its presence could be shown, and its concentration determined, by preliminary treatment with a suitable reducing agent. On indirect evidence Tunnicliffe (1925), using iodometric determination of GSH, reported that no GSSG was present in deproteinized filtrates of rabbit and rat tissues, and for the same species this conclusion was reached also by Dohan \& Woodward (1939), using the specific glyoxalase method for determining GSH and electrolytic reduction for the conversion of any GSSG into GSH. On the other hand, Thompson \& Voegtlin (1926) found that treatment of blood and tissue trichloroacetic acid filtrates from a variety of animal species, particularly rat, with magnesium produced an increase in the apparent amount of GSH determined iodometrically, the increase corresponding to the existence of not more than $10 \%$ of the glutathione in the disulphide form. A much larger increase in apparent GSH after reduction with magnesium was found in blood by Schelling (1932), who used the ferricyanide method of Mason (1930) but who considered the increase due to the reduction of substances other than GSSG. Fujita \& Numata $(1938 b, d)$ considered blood and tissue filtrates from various animal species to contain considerable amounts of GSSG on the basis of increases in GSH (determined by nitroprusside or by iodine) following reduction with hydrogen sulphide. This work, however, was criticized by Dohan \& Woodward (1939), who showed that under the conditions employed traces of hydrogen sulphide might be retained in the filtrates and react with sufficient iodine to simulate quite considerable amounts of newly formed GSH. Although numerous papers, since 1939, have reported determinations of GSH before and after treatment of blood and tissue filtrates by reducing agents, no new method has been introduced, and the published figures are such that no definite pronouncement can yet be made as to the existence of GSSG in vivo.

In trials of Dohan \& Woodward's method (1939) for determining glutathione we obtained results which suggested the desirability of a minor modification. The object of this paper is to describe this modification and to report that, with the new procedure, the figures suggest that blood (rat, rabbit, human) does contain a little glutathione in the disulphide form.

\section{EXPERIMENTAL}

Glutathione, in the sulphydryl form, was determined either iodometrically, or by the glyoxalase method (Woodward, 1935). Reduction of the disulphide form of glutathione was accomplished by means of zinc dust, or electrolytically. For the zinc reduction and the iodometric determination the procedure of Woodward \& Fry (1932) was followed exactly.

Preparation of blood and tissue filtrates. Proteins were removed by precipitation with sulphosalicylic acid, the concentration of which was varied from 2 to $4 \%(w / v)$ in earlier experiments and was finally fixed at $3 \%(w / v)$. Blood was heparinized, and 1 vol. was added very slowly with constant shaking to 4 vol. of sulphosalicylic acid solution. Very thorough shaking was necessary to ensure complete extraction of glutathione, since no preliminary haemolysis of the blood was undertaken. For tissues, a suitable amount was added to 5-7 ml. of sulphosalicylic acid solution and weighed. It was then ground with acidwashed sand using an all-glass mortar and pestle, the fluid being poured into a volumetric flask. The grinding was repeated several times with more sulphosalicylic acid solution, and the combined extracts were made up to standard volume and filtered. In all filtrates, whether of blood or tissue, the aim was to keep the glutathione concentration below $0.2 \mathrm{mg} . / \mathrm{ml}$.

Glyoxalase method. The determination of glutathione by the glyoxalase method depends upon measurement, in a Warburg manometer, of the $\mathrm{CO}_{2}$ evolved under controlled conditions of time and $\mathrm{pH}$ by a mixture of washed yeast as enzyme source and methylglyoxal.

Fresh baker's yeast (Distillers Co. Ltd., Edinburgh) was dried as described by Albert, Buchner \& Rapp (1902) and stored with refrigeration. For use, glutathione was removed from this acetone-dried material by suspending $2-3 \mathrm{~g}$. in about $80 \mathrm{ml}$. of water, shaking thoroughly, centrifuging, and discarding the supernatant fluid; this was repeated three times. Finally, the washed yeast was made up as a $33-36 \%(w / v)$ suspension in water. This concentration was chosen since $0.5 \mathrm{ml}$. of the suspension with $0.1 \mathrm{mg}$. of glutathione added along with the substrate $(0.2 \mathrm{ml}$. of $1 \%$ methylglyoxal) and $0.4 \mathrm{ml}$. of $0.2 \mathrm{M}-\mathrm{NaHCO}_{3}$ produced approximately $200 \mu \mathrm{l}$. of $\mathrm{CO}_{2}$ in $20 \mathrm{~min}$. The methylglyoxal was prepared by dilution of a $30 \%$ aqueous stock solution (L. Light and Co. Ltd., Bucks). Glutathione, 99.8\% pure, was supplied by the Yeast Research Outstation of the Distillers Co. Ltd., Glenochil, Menstrie, Clackmannanshire; standard aqueous solutions were prepared containing respectively, $0.05,0.10$ and $0.20 \mathrm{mg} . / \mathrm{ml}$.

The use of sulphosalicylic acid and its subsequent neutralization (Herrmann \& Moses, 1945) for making the standard solutions was found to be unnecessary.

The washed yeast suspension, the methylglyoxal and the $\mathrm{NaHCO}_{3}$ solutions were first added to the main chambers of all the manometer flasks. Next, into the side bulbs of the standard flasks were measured the glutathione solutions $\left(0.5 \mathrm{ml}\right.$.) and of the others that volume of $0.8 \mathrm{M}-\mathrm{NaHCO}_{3}$ solution required (determined by separate titration) to neutralize the sulphosalicylic acid filtrate to methyl orange. After the standard flasks had been fitted to the manometers, the others received, in the side bulbs, their charge of blood or tissue filtrate and they, too, were immediately fitted to the manometers. The gas mixture used was $5 \%$ $(\mathrm{v} / \mathrm{v}) \mathrm{CO}_{2}$ in $\mathrm{N}_{2}$ and the temperature was $25^{\circ}$. After the 
contents of the side bulb and main chamber were mixed, the manometers were shaken for $4 \mathrm{~min}$. with taps open, and thereafter, with taps closed, readings were taken at intervals of $5 \mathrm{~min}$. for $25 \mathrm{~min}$; the reading at the end of the first 5 min. was taken as the starting point and the $\mathrm{CO}_{2}$ production during the remaining $20 \mathrm{~min}$. used as the basis of the determination.

Electrolytic reduction. The technique of Dohan \& Woodward (1939) was used. The cathode vessel had a diameter of $3.5 \mathrm{~cm}$., the salt bridge a bore of $4.5 \mathrm{~mm}$. The current was supplied from a $240 \mathrm{v}, 50$ cyc./sec., a.c. main supply through a rectifier, and until the conditions were finally stabilized as the result of experiment the current density was varied by means of a $2500 \Omega$ variable resistance capable of carrying $0.3 \mathrm{~A}$ between 2.5 and $4.3 \mathrm{~mA} / \mathrm{cm} .^{2}$. The time of reduction was varied in relation to the volume of solution used and the current density as recommended by Dohan \& Woodward (1939).

\section{RESULTS AND DISCUSSION}

\section{Recovery of GSH and GSSG added to} plasma or whole blood

Glutathione (GSH) added to five samples of human plasma and determined by the glyoxalase method was recovered to the extent of 96-100\% (mean 98.8\%); in the case of whole blood the recovery from seven samples ranged from 93 to $104 \%$ (mean 97.1\%) (Table 1). When oxidized glutathione was added, and reduced by zinc, only
$69 \%$ could be recovered from whole blood as GSH and only $52 \%$ from plasma in these experiments; determination of GSH was iodometric because the presence of zinc salts interferes with the glyoxalase method. Nevertheless, in pure aqueous solution, GSSG was quantitatively reduced by the zinc method. These results confirm those of Dohan \& Woodward (1939).

Table 1. Recovery of glutathione added to human plasma or whole blood using the glyoxalase method

\begin{tabular}{cccc}
\multicolumn{2}{c}{ GSH (mg./100 ml.) } & \\
Added & $\begin{array}{c}\text { Calc. } \\
\text { Blood }\end{array}$ & $\begin{array}{c}\text { Found } \\
\text { plasma }\end{array}$ & $\begin{array}{r}\text { Recovery } \\
(\%)\end{array}$ \\
30 & 30 & 30 & 100 \\
50 & 50 & 49 & 98 \\
50 & 50 & 50 & 100 \\
25 & 25 & 25 & 100 \\
25 & 25 & 24 & 96 \\
& Whole blood & \\
10 & 32 & 31 & 97 \\
10 & 32 & 30 & 94 \\
40 & 54 & 53 & 98 \\
40 & 54 & 50 & 93 \\
40 & 52 & 49 & 94 \\
20 & 56 & 58 & 104 \\
20 & 56 & 56 & 100
\end{tabular}

Table 2. Recovery of oxidized glutathione added to human plasma using the glyoxalase method after electrolytic reduction

Group $A$ with $\mathrm{H}_{2} \mathrm{O}_{2}$ and group $B$ with $\mathrm{I}_{2}$ as oxidizing agent for preparation of GSSG.

\begin{tabular}{|c|c|c|c|c|c|}
\hline \multirow[b]{2}{*}{$\begin{array}{c}\text { GSSG } \\
\text { added } \\
\text { (mg./100 ml.) }\end{array}$} & \multirow[b]{2}{*}{$\begin{array}{c}\text { Found as } \\
\text { GSH } \\
\text { (mg./100 ml.) }\end{array}$} & & \multicolumn{3}{|c|}{ Conditions of reduction } \\
\hline & & $\begin{array}{c}\text { Recovery } \\
(\%)\end{array}$ & $\begin{array}{l}\text { Volume } \\
\text { reduced } \\
\text { (ml.) }\end{array}$ & $\begin{array}{c}\text { Current } \\
\text { density } \\
\left.\text { (m//cm. }{ }^{2}\right)\end{array}$ & $\begin{array}{c}\text { Time of } \\
\text { reduction } \\
\text { (min.) }\end{array}$ \\
\hline \multicolumn{6}{|c|}{ Group $A$} \\
\hline 50 & 44 & 88 & 5 & $4 \cdot 3$ & 10 \\
\hline 50 & 39 & 78 & 10 & $2 \cdot 5$ & 20 \\
\hline 50 & 44 & 88 & $\mathbf{5}$ & $4 \cdot 3$ & 10 \\
\hline 50 & 42 & 84 & 10 & 2.5 & 20 \\
\hline 30 & 29 & 97 & 5 & $4 \cdot 3$ & 10 \\
\hline 30 & 29 & 97 & $\mathbf{5}$ & $4 \cdot 3$ & 10 \\
\hline 25 & 23 & 92 & 5 & $4 \cdot 3$ & 10 \\
\hline 25 & 23 & 92 & 5 & $4 \cdot 3$ & 10 \\
\hline 50 & 42 & 84 & 5 & $4 \cdot 3$ & 10 \\
\hline 50 & 42 & 84 & 5 & $4 \cdot 3$ & 10 \\
\hline 50 & 42 & 84 & 5 & $4 \cdot 3$ & 10 \\
\hline 50 & 41 & 82 & 5 & $4 \cdot 3$ & 10 \\
\hline 50 & 49 & 98 & 5 & $4 \cdot 3$ & 10 \\
\hline 50 & 49 & 98 & 5 & $4 \cdot 3$ & 10 \\
\hline 25 & 24 & 96 & 5 & $4 \cdot 3$ & 10 \\
\hline \multicolumn{6}{|c|}{ Group $B$} \\
\hline 50 & 50 & 100 & 5 & $4 \cdot 3$ & 10 \\
\hline 30 & 29 & 97 & 10 & 2.5 & 20 \\
\hline 30 & 30 & 100 & 10 & 2.5 & 20 \\
\hline 30 & 31 & 103 & 10 & $2 \cdot 5$ & 20 \\
\hline $\mathbf{5 0}$ & 50 & 100 & 10 & 2.5 & 25 \\
\hline 50 & 51 & 102 & 10 & $2 \cdot 5$ & 25 \\
\hline 50 & 49 & 98 & 5 & $4 \cdot 3$ & 10 \\
\hline 50 & 50 & 100 & 5 & $4 \cdot 3$ & 10 \\
\hline 50 & 48 & 96 & 5 & $4 \cdot 3$ & 10 \\
\hline
\end{tabular}


The results obtained when GSSG added to human plasma was determined as GSH by the glyoxalase method after electrolytic reduction are summarized in Table 2. When the oxidized glutathione was prepared from the reduced form by means of hydrogen peroxide, the subsequent recovery from 15 samples of plasma ranged from 78 to $98 \%$ (mean $89.4 \%$ ). These low recoveries may have been due to some destruction of the glutathione molecule for, when oxidation of GSH was achieved by addition of the theoretical amount of $0.01 \mathrm{~N}$ iodine, the subsequent recovery by electrolytic reduction and glyoxalase determination of GSH was uniformly good. In nine samples of plasma recoveries ranged from 96 to $103 \%$ (mean $99.5 \%$ ). Recoveries from whole blood were of similar magnitude. Control experiments showed that hydriodic acid did not interfere.

\section{The electrolytic reduction of GSSG in blood filtrates}

It was noticed that, when blood filtrates were made with the prescribed amount of 2 or $2.3 \%$ sulphosalicylic acid (Dohan \& Woodward, 1939) and electrolytically reduced for $10 \mathrm{~min}$. with a current density of $4.3 \mathrm{~mA} / \mathrm{cm}^{2}$, the $\mathrm{pH}$ rose above $4 \cdot 0$. In such filtrates the GSH content, determined by the glyoxalase method, was often considerably lower after reduction than before (Table 3). Woodward \& Fry (1932) showed that glutathione undergoes moderately rapid oxidation when solutions with $\mathrm{pH}$ above 3.0 are exposed to air, although it is stable under similar conditions if the $\mathrm{pH}$ is kept about 2.0. The determination of GSH in a number of blood filtrates inevitably involves a period of standing after the electrolytic reduction, some- times as long as $1 \mathrm{hr}$., before the actual manometric measurements are begun. It is evident that the $\mathrm{pH}$ of the solution after electrolytic reduction should be kept below 3.0, and experiments were therefore made in which filtrates were prepared with sulphosalicylic acid solutions of various concentrations, the $\mathrm{pH}$ being measured before and after electrolytic reduction. At the same time, the influence of the current density was investigated. The results are recorded in Table 4.

When 2 or $2.3 \%$ sulphosalicylic acid was used, the $\mathrm{pH}$ was about 1.8 before reduction but rose to over 3.5 and often over 4 when the current density was about $4.3 \mathrm{~mA} / \mathrm{cm}^{2}$, and over 3.0 even when the current density was reduced to about $2.5 \mathrm{~mA} / \mathrm{cm} .^{2}$. Sulphosalicylic acid of $3 \%$ concentration, however, gave a filtrate of $\mathrm{pH}$ about 1-1.4 before reduction, and never above 2.4 even after reduction, irrespective of the current density used. Under these conditions the apparent loss of GSH shown in Table 3 with $2 \%$ sulphosalicylic acid did not occur.

Table 3. Apparent glutathione content of whole blood after electrolytic reduction (when the $\mathrm{pH}$ rose above 4.0) using the glyoxalase method

Concn. of
sulphosalicylic
acid
$(\%, w / v)$
2
2
2
$2 \cdot 3$
$2 \cdot 3$

\begin{tabular}{|c|c|}
\hline \multicolumn{2}{|c|}{ GSH (mg./100 ml.) } \\
\hline $\begin{array}{l}\text { Before } \\
\text { reduction }\end{array}$ & $\begin{array}{l}\text { After } \\
\text { reduction }\end{array}$ \\
\hline $\begin{array}{l}38 \\
58 \\
42 \\
23 \\
37\end{array}$ & $\begin{array}{l}34 \\
45 \\
18 \\
20 \\
37\end{array}$ \\
\hline
\end{tabular}

Table 4. $\mathrm{pH}$ values of sulphosalicylic acid filtrates before and after electrolytic reduction

\begin{tabular}{|c|c|c|c|c|c|}
\hline \multirow{3}{*}{$\begin{array}{c}\text { Concn. of } \\
\text { sulphosalicylic } \\
\text { acid } \\
(\%, w / v)\end{array}$} & \multirow{2}{*}{\multicolumn{2}{|c|}{$\mathrm{pH}$}} & \multicolumn{3}{|c|}{ Conditions of reduction } \\
\hline & & & \multirow{2}{*}{$\begin{array}{l}\text { Volume } \\
\text { reduced } \\
\text { (ml.) }\end{array}$} & \multirow{2}{*}{$\begin{array}{c}\text { Current } \\
\text { density } \\
\left.\text { (mA/cm. }{ }^{2}\right)\end{array}$} & \multirow{2}{*}{$\begin{array}{l}\text { Time of } \\
\text { reduction } \\
\text { (min.) }\end{array}$} \\
\hline & $\begin{array}{l}\text { Before } \\
\text { reduction }\end{array}$ & $\begin{array}{c}\text { After } \\
\text { reduction }\end{array}$ & & & \\
\hline \multicolumn{6}{|c|}{ Blood filtrate } \\
\hline $2 \cdot 0$ & $1 \cdot 8$ & $3 \cdot 4$ & 10 & $2 \cdot 5$ & 20 \\
\hline $2 \cdot 3$ & 1.8 & $3 \cdot 2$ & 10 & $2 \cdot 5$ & 20 \\
\hline $2 \cdot 3$ & 1.8 & $5 \cdot 7$ & 5 & $4 \cdot 3$ & 10 \\
\hline $2 \cdot 3$ & $1 \cdot 8$ & $4 \cdot 4$ & 5 & $4 \cdot 3$ & 10 \\
\hline $2 \cdot 3$ & $1 \cdot 7$ & $6 \cdot 4$ & 5 & $4 \cdot 3$ & 10 \\
\hline $2 \cdot 3$ & $1 \cdot 6$ & $6 \cdot 1$ & 5 & $4 \cdot 3$ & 10 \\
\hline $2 \cdot 3$ & 1.6 & 3.5 & 5 & $4 \cdot 3$ & 10 \\
\hline $\mathbf{3} \cdot 0$ & 1.4 & 1.8 & 10 & $2 \cdot 5$ & 20 \\
\hline $3 \cdot 0$ & 1.4 & 1.7 & 10 & $2 \cdot 5$ & 20 \\
\hline $3 \cdot 0$ & 1.5 & 1.9 & 10 & $2 \cdot 5$ & 20 \\
\hline $3 \cdot 0$ & $1 \cdot 3$ & $2 \cdot 0$ & 5 & $4 \cdot 3$ & 10 \\
\hline $3 \cdot 0$ & $1 \cdot 4$ & $2 \cdot 4$ & 5 & $4 \cdot 3$ & 10 \\
\hline $3 \cdot 0$ & 1.5 & $2 \cdot 4$ & 5 & $4 \cdot 3$ & 10 \\
\hline $3 \cdot 0$ & $1 \cdot 3$ & $2 \cdot 1$ & $\mathbf{5}$ & $4 \cdot 3$ & 10 \\
\hline \multicolumn{6}{|c|}{ Liver filtrate } \\
\hline $3 \cdot 0$ & $1 \cdot 1$ & $1 \cdot 3$ & 5 & $4 \cdot 3$ & 10 \\
\hline $3 \cdot 0$ & $1 \cdot 0$ & $1 \cdot 2$ & 5 & $4 \cdot 3$ & 10 \\
\hline
\end{tabular}


In all subsequent experiments, therefore (including those reported in Table 2 ), $3 \%$ sulphosalicylic acid was used as the protein-precipitating agent.

\section{The existence of GSSG in blood}

When, in the presence of $3 \%$ sulphosalicylic acid, GSH in aqueous solution was measured before and after the electrolytic reduction procedure, the two figures obtained were identical; reduction produced neither apparent loss nor apparent gain. On the other hand, when whole blood filtrates were examined in the same way, the amount of GSH measured by the glyoxalase method was regularly greater after electrolytic reduction than before (Tables 5 and 7). Because of the specificity of the

\section{Table 5. Glutathione content of rat and rabbit blood}

Electrolytic reduction of GSSG and determination of GSH by the glyoxalase method. Rat blood obtained from abdominal aorta under Nembutal anaesthesia; rabbit blood by cardiac puncture without anaesthesia. Heparin was used as anticoagulant in all cases. The mean results (ranges in parentheses) are expressed in $\mathrm{mg} . / 100 \mathrm{ml}$. blood.

$\begin{array}{lcccc} & \begin{array}{c}\text { No. of } \\ \text { animals }\end{array} & \text { GSH } & \text { GSSG } & \begin{array}{c}\text { Total } \\ \text { GSH }\end{array} \\ \text { Rat } & 6 & 18 & 22 & 40 \\ \text { Rabbit } & 10 & (16-23) & (20-25) & (38-48) \\ & & (22-43) & (7-21) & (29-54)\end{array}$

glyoxalase method of determining GSH and because of the excellent recoveries of GSSG added to blood and plasma (Table 2) this appeared to indicate the presence of GSSG in the blood filtrates. It seemed possible, however, that the GSSG did not really exist in the original blood but was produced from GSH during the preparation of the filtrate.

It was observed, in the first place, that although thorough shaking (30 sec.) or long standing (30 min.) was necessary during the preparation of the filtrate in order to ensure complete extraction of glutathione from the blood cells, shaking for as much as $10 \mathrm{~min}$. did not cause oxidation of GSH to GSSG. Nor was there any evidence of GSH oxidation in the blood before protein precipitation. If blood was taken direct into $3 \%$ sulphosalicylic acid at room temperature or even cooled to $0^{\circ}$, the apparent content of GSH and GSSG was the same as when the blood was withdrawn in the usual way into a syringe, transferred to a test tube and then, after a few minutes, pipetted into the sulphosalicylic acid solution.

Numata (1940) reported that glutathione in blood appeared to be oxidized during deproteinization with metaphosphoric acid, and recommended, as a means of preventing this, that blood or tissues with a high haemoglobin content should be saturated with carbon monoxide before deproteinization. The observations just mentioned, as well as the recovery experiments with added GSH and GSSG suggested that sulphosalicylic acid did not cause oxidation. As a confirmatory experiment, however, GSH was measured in blood filtrates before and after electrolytic reduction in two samples of the same blood, one of which was saturated with carbon monoxide, whilst the other remained untreated. Treatment with carbon monoxide did not appear to have any adverse effect on the glyoxalase system, for aqueous solutions of glutathione gave the same GSH concentration whether or not they had previously been saturated with carbon monoxide (Table 6). In the case of the blood filtrates the previous treatment of the blood with carbon monoxide produced an increase of about 5-8 mg./100 ml. in the apparent glutathione content of the blood, both before and after electrolytic reduction (Table 6). The difference in the GSH

Table 6. Effect of saturation with carbon monoxide on the apparent glutathione content of blood and aqueous solutions of GSH

\begin{tabular}{|c|c|c|c|}
\hline \multicolumn{4}{|c|}{ GSH (mg./100 ml.) } \\
\hline \multicolumn{2}{|c|}{$\begin{array}{l}\text { Before electrolytic } \\
\text { reduction }\end{array}$} & \multicolumn{2}{|c|}{$\begin{array}{l}\text { After electrolytic } \\
\text { reduction }\end{array}$} \\
\hline $\begin{array}{l}\text { Before } \\
\text { saturation }\end{array}$ & $\underset{\text { saturation }}{\text { After }}$ & $\begin{array}{l}\text { Before } \\
\text { saturation }\end{array}$ & $\begin{array}{c}\text { After } \\
\text { saturation }\end{array}$ \\
\hline \multicolumn{4}{|c|}{ Blood } \\
\hline 28 & 34 & 45 & 50 \\
\hline 24 & 31 & 40 & 48 \\
\hline \multicolumn{4}{|c|}{ Aqueous GSH solution } \\
\hline 11 & 11 & 一 & 一 \\
\hline 12 & 11 & 一 & - \\
\hline
\end{tabular}

content produced by reduction was the same with and without the preliminary treatment with carbon monoxide. It is possible that the carbon monoxide has in some way allowed some substance other than glutathione to react in the glyoxalasecontaining system or that a little GSH has been liberated from a normally non-reactive complex. However, the experiments provide no evidence to support the view that GSSG is formed during deproteinization.

It seems justifiable, then, to conclude that the blood of the three species we have examined-man, rabbit, rat-does contain a small amount of glutathione in the oxidized, disulphide, form. The contrary conclusion of Dohan \& Woodward (1939), in support of which the results of only two determinations are published, may have been due to their use of sulphosalicylic acid $(2 \cdot 3 \%)$ such that the $\mathrm{pH}$ rose during reduction to a level which permitted subsequent loss of GSH. Under their 
conditions of sulphosalicylic acid concentration, but with the current density in the electrolytic reduction lowered to $2.5 \mathrm{~mA} / \mathrm{cm}^{2}$ (which produces a smaller $\mathrm{pH}$ increase than does $4.2 \mathrm{~mA} / \mathrm{cm}^{2}$ ), we found some increase in GSH after reduction. The essential difference between our procedure and that of Dohan \& Woodward (1939) thus seemed to lie in the $\mathrm{pH}$ control during reduction. Since, however, these workers, though mentioning the glyoxalase method, had employed the iodometric method of determining GSH, it seemed desirable to examine this method when applied to material submitted to electrolytic reduction with the $\mathrm{pH}$ kept below 3.0. For complete comparison a series of experiments using human blood was made as follows.

Venous blood, withdrawn into heparinized syringes, was deproteinized immediately with $3 \%$ $(w / v)$ sulphosalicylic acid solution. Four samples of the filtrate were examined: GSH was determined iodometrically in one and by the glyoxalase method in a second; a third was treated with zinc dust and thereafter GSH was measured iodometrically; the fourth was reduced electrolytically and then subdivided so that GSH could be measured both by iodate titration and by the glyoxalase method (Table 7). The apparent GSH increases by
1935), for in thirteen instances of analysis by both methods the ratio of the results was $1.00 \pm 0.121$ (range $0 \cdot 81-1 \cdot 16$ ) and the means were not statistically different. When oxidized glutathione was determined by electrolytic reduction, the results given in twelve samples of blood by iodate titration were significantly higher than those obtained in the same samples using the glyoxalase method, the ratio being $1 \cdot 37 \pm 0 \cdot 376$ (range $1 \cdot 00-2 \cdot 20$ ). This was also the case when iodometric measurement was preceded by zinc reduction, the ratio (iodometry/ manometry) being $1 \cdot 32 \pm 0 \cdot 493$ (range $0 \cdot 83-2 \cdot 25$ ). Iodate titration consistently gives slightly higher results, after reduction, than the specific manometric glyoxalase method. This indicates that during the reduction process substances are produced which are oxidizable by iodate but which are not GSH, since they fail to activate glyoxalase. On this basis, since zinc reduction of GSSG is inefficient, permitting only $70 \%$ recovery of added GSSG, whereas electrolytic reduction gives $100 \%$ reduction, and since substances interfering with iodate titration are formed in both reduction procedures, one would expect the apparent amount of GSSG to be greater by electrolytic reduction than by zinc reduction, the GSH formed being deter-

\section{Table 7. Glutathione analyses of human blood by various methods}

Blood obtained from the cubital vein, with heparin as anticoagulant. The results are expressed in mg./100 ml. blood.

\begin{tabular}{|c|c|c|c|c|c|c|c|c|}
\hline \multirow[b]{3}{*}{ Sample no. and diagnosis } & \multicolumn{5}{|c|}{ Iodometric method } & \multicolumn{3}{|c|}{ Glyoxalase method } \\
\hline & \multirow[b]{2}{*}{ GSH } & \multicolumn{2}{|c|}{$\begin{array}{l}\text { Zinc } \\
\text { reduction }\end{array}$} & \multicolumn{2}{|c|}{$\begin{array}{l}\text { Electrolytic } \\
\text { reduction }\end{array}$} & \multirow[b]{2}{*}{ GSH } & \multicolumn{2}{|c|}{$\begin{array}{l}\text { Electrolytic } \\
\text { reduction }\end{array}$} \\
\hline & & GSSG & $\begin{array}{l}\text { Total } \\
\text { GSH }\end{array}$ & GSSG & $\begin{array}{l}\text { Total } \\
\text { GSH }\end{array}$ & & GSSG & $\begin{array}{l}\text { Total } \\
\text { GSH }\end{array}$ \\
\hline 1. Normal & 30 & 7 & 37 & 8 & 38 & 37 & 6 & 43 \\
\hline 2. Diabetes mellitus & 17 & 6 & 23 & 7 & 24 & 17 & 7 & 24 \\
\hline 3. Duodenal ulcer & 27 & 11 & 38 & 11 & 38 & 32 & 6 & 38 \\
\hline 4. Sciatica & 27 & 7 & 34 & 7 & 34 & 31 & 7 & 38 \\
\hline 5. Duodenal ulcer & 29 & $\mathbf{5}$ & 34 & 6 & 35 & 26 & 5 & 31 \\
\hline 6. Normal & 37 & 5 & 42 & 6 & 43 & 41 & 6 & 47 \\
\hline 7. Normal & 29 & 8 & 37 & 9 & 38 & 25 & 6 & 31 \\
\hline 8. Neuritis & 27 & 8 & 35 & 11 & 38 & 27 & 7 & 34 \\
\hline 9. Epilepsy & 31 & 7 & 38 & 9 & 40 & 32 & 8 & 40 \\
\hline 10. Normal & 29 & 8 & 37 & 8 & 37 & 26 & $\mathbf{5}$ & 31 \\
\hline 11. Normal & 33 & 8 & 41 & 8 & 41 & 29 & 7 & 36 \\
\hline 12. Diabetes mellitus & 26 & 11 & 37 & 11 & 37 & 23 & $\mathbf{5}$ & 28 \\
\hline 13. Normal & 37 & 9 & 46 & - & - & 35 & 4 & 39 \\
\hline
\end{tabular}

whichever method it is determined, and the significance of this is examined statistically, interpretation being based on the conclusion that the specific glyoxalase method, combined with the effective electrolytic reduction under $\mathrm{pH}$ conditions which preserve GSH from reoxidation, gives a measure of oxidized glutathione.

For the measurement of preformed GSH in blood the iodometric method and the glyoxalase method are equally reliable (as was found by Woodward, mined by iodometry; this is indeed the case, as is shown by the fact that the results obtained by using both methods on the same blood samples gave a ratio (zinc reduction/electrolytic reduction) of $0 \cdot 89 \pm 0 \cdot 101$ (range $0 \cdot 72-1 \cdot 00$ ).

\section{The existence of GSSG in tissues}

In contrast to blood, extracts of liver, pancreas and kidney from rabbits or rats, prepared with $3 \%$ sulphosalicylic acid, showed no consistent increase 
in glutathione content using the glyoxalase method and electrolytic reduction (Table 8). This result, indicating that no appreciable quantities of GSSG exist in these tissues (the reduction of this substance during extraction is improbable), is in agreement with the findings of Dohan \& Woodward (1939) and Herrmann \& Moses (1945). In the course of these measurements we found, as Woodward (1935) had done, that the iodometric method gave

Table 8. Glutathione content of rat and rabbit tissues ( $m g . / 100 \mathrm{~g}$.$) before and after electrolytic reduction$ using the glyoxalase method

The results are means with ranges in parentheses.

$\begin{array}{lccc} & \begin{array}{c}\text { No. of } \\ \text { expts. }\end{array} & \begin{array}{c}\text { Before } \\ \text { reduction }\end{array} & \begin{array}{c}\text { After } \\ \text { reduction }\end{array} \\ \text { Rat liver } & 6 & 218 & 212 \\ \text { Rat pancreas } & 4 & (134-297) & (150-261) \\ \text { Rat kidney } & 3 & 51 & 53 \\ & & (46-60) & (47-60) \\ \text { Rabbit liver } & 2 & (67-108) & (67-101) \\ \text { Rabbit pancreas } & 2 & 264 & 268 \\ & & (243-284) & (251-284) \\ & & (31-50) & (41-50)\end{array}$

erroneously high results in tissue extracts, although in blood filtrates its agreement with the manometric method was good. Ennor (1939), on the other hand, considered that the error lay in the glyoxalase manometric method, the contention being that sulphosalicylic acid interfered with the activity of the enzyme. Actually his experimental results showed that glutathione was accurately measured by the glyoxalase method in the presence of sulphosalicylic acid, and our own investigations have amply confirmed this.

\section{SUMMARY}

1. The reduced glutathione (GSH) content of blood can be estimated equally well by the iodometric and glyoxalase methods. Only the latter method is reliable for the estimation of GSH in tissues.

2. Slight modifications in the procedure of Dohan \& Woodward (1939) have been suggested for the accurate estimation of total glutathione (reduced plus oxidized) in blood using the glyoxalase method and electrolytic reduction.

3. It has been demonstrated by the modified technique that considerable amounts of oxidized glutathione (GSSG) are present in blood cells (human, rabbit and rat).

4. The iodometric method is unreliable for the accurate estimation of total glutathione in blood since interfering substances are liberated during the reduction of GSSG to GSH.

5. Unlike blood, tissues (liver, kidney, pancreas) of rabbits and rats do not contain any measurable quantity of GSSG.

One of us (S.K.B.) wishes to thank the University of Edinburgh for a Post-Graduate Research Fellowship which made possible his participation in this work.

\section{REFERENCES}

Albert, R., Buchner, E. \& Rapp, R. (1902). Ber. dtsch. chem. Ges. 35, 2376. Quoted by Umbreit, W. W., Burris, R. H. \& Stauffer, J. F. (1949). Manometric Techniques, p. 179. Minneapolis: Burgess Publishing Co.

Benedict, S. R. \& Gottschall, G. (1933). J. biol. Chem. 99, 729.

Benesch, R. E. \& Benesch, R. (1950). Arch. Biochem. 28, 43.

Dohan, J. S. \& Woodward, G. E. (1939). J. biol. Chem. 129, 393.

Ennor, A. H. (1939). Aust. J. exp. biol. Med. Sci. 17, 157.

Fujita, A. \& Numata, I. (1938a). Biochem. Z. 299, 249.

Fujita, A. \& Numata, I. (1938b). Biochem. Z. 299, 262.

Fujita, A. \& Numata, I. (1938c). Biochem. Z. 300, 246.

Fujita, A. \& Numata, I. $(1938 d)$. Biochem. Z. 300, 257.

Grunert, R. R. \& Phillips, P. H. (1951). Arch. Biochem. 30, 217.

Herrmann, H. \& Moses, S. G. (1945). J. biol. Chem. 158, 33.

Lohmann, K. (1932). Biochem. Z. 254, 332.

Mason, H. L. (1930). J. biol. Chem. 86, 623.

Numata, I. (1940). Biochem. Z. 304, 404.

Potter, V. R. \& Franke, K. W. (1935). J. Nutr. 9, 1.

Schelling, V. (1932). J. biol. Chem. 96, 17.

Thompson, J. W. \& Voegtlin, C. (1926). J. biol. Chem. 70, 793.

Tunnicliffe, H. E. (1925). Biochem. J. 19, 194.

Woodward, G. E. (1935). J. biol. Chem. 109, 1.

Woodward, G. E. \& Fry, E. G. (1932). J. biol. Chem. 97, 465. 